\title{
Inclusive Growth and Sustainable Human Development in Nigeria.
}

\author{
Campbell, Omolara A (PhD) \\ Lead City University, \\ Challenge, Ibadan. Oyo State.
}

\begin{abstract}
Previous studies have confirmed the position that higher education is a sine-qua-non for human capital development and economic growth. The 2014 rebasing of Gross Domestic Product made Nigeria the $26^{\text {th }}$ largest economy in the world and the biggest in Africa. Recently, the International Monetary Fund (IMF) pronounced Nigeria again as having the largest economy in Africa. Yet Africa's largest economy faces a myriad of challenges, such as high prevalence of poverty, unemployment, underemployment, youth unemployment, huge infrastructure deficits, income and social inequalities. However, the Sustainable Development Goals (SDGs) has its goal 8 as "promoting sustained, inclusive and sustainable economic growth, full and productive employment and decent work for all" by 2030 . Based on this background, this paper proceeds to examine how human development can translate to inclusive economic growth. It focuses mainly on enhancement of human capabilities which is one of the key drivers of inclusive growth. It assesses the status and performance of the indicators of human development in Nigeria and compares the outcomes with that of the emerging and developed nations. Utilizing secondary data and descriptive statistical analytical tools, the paper finds out that the indices of human development and the knowledge economy recorded higher values in the emerging and developed countries than what exists in the developing countries. The paper therefore recommends the urgent need for policy makers to formulate appropriate policy mix that will ensure increase in investment in human capital and all indices of human development and knowledge economy. This is expected to be via improvement in quantity and quality of education in general and higher education in particular for individuals to contribute to and benefit from economic growth.
\end{abstract}

Key Words: Human Development, Human Development Indices, Inclusive Growth and Knowledge Economy Indices.

\section{INTRODUCTION}

The call for inclusive growth (IG) has been unanimously declared by policy makers across the world. The concept of(IG) is a broad term that ensures that economic growth benefits all segments of the society including the poor, near poor with meager incomes, the middle class and even the rich. Conceptualized in this form, IG is growth that reduces the disadvantages of the vulnerable and most disadvantaged while benefitting everyone. IG is an economic growth performance that encompasses equity, equality in both income and opportunities coupled with protection in market and employment (Growth Report, 2010). It is enhanced with rapid and sustained Gross Domestic Product (GDP) by a leading sector of the economy not necessarily all sectors of the economy. IG is both an outcome and a process. It ensures everyone participates in growth process both in terms of decision making for organizing the growth progression as well as in participating in the growth itself. Rapid pace of growth is seen as unquestionably necessary for substantial poverty reduction. However, for growth to be sustainable in the long run, it has to be broad based across the sectors of the economy and involve a large part of the country's labor force. IG entails achieving sustainable growth that will create and expand 
economic opportunities and ensure broader access to these opportunities so that members of the society can participate in and benefit from economic growth. The pursuit of IG agenda entails firstly, boosting and modernizing agriculture, which provides livelihood for majority of the populace. Secondly, improving the investment and business climate, and providing support for indigenous micro and small businesses. Thirdly, providing and facilitating access to better quality and relevant education and training. Finally, IG involves broadening participation in the development process. The World Bank (2009) in its own submission hints that inclusive growth can be achieved by expanding access to assets and thriving markets.

Human Development (HD) on the other hand is a multidimensional and complex concept, partly as a result of the complexity of human nature. The general goal of HD is to enhance the quality of human life which will enable people to live long and productive lives, enjoy good health, have access to knowledge and educational opportunities among others. The Human Development Index (HDI) of the United Nations Development Programme is quantifiable approximations of a subjective and qualitative concept of the quality of life. It reminds us that development is all about human development and not just higher income. Thus it shifts focus away from the traditional measure of economic performance (growth in GDP) to a more holistic measure of development (Oladeji, 2014). The HDI is based on three indicators: Longevity, measured by life expectancy at birth, educational attainment, as measured by a combination of adult literacy and the combined gross primary, secondary and tertiary enrolment coupled with standard of living as measured by real gross domestic product per capita. The HDI underscores the basic variables that underlie sustainability in economic development.

Ranis (2004) using human development interchangeably with human capital indicated a twoway relationship between economic growth and human development and made an outstanding suggestion that nations may enter either into a vicious cycle of high growth and large gains in human development, or a vicious cycle of low growth and low rates of human development improvement. In his opinion, the levels of economic growth and human development are mutually reinforcing, either leading towards an upward spiral of development, or a poverty trap. However, the existence and persistence of these cycles depends on the strengths of the linkages between economic growth and human development. He made remarkable assertions concerning the state of developing nations; he noted that countries may find themselves in a lop-sided state, at least temporarily, with relatively good growth and relatively poor human development, or vice versa. And he advanced reasons for such situations as including government corruption, low social expenditures, and inequitable income distribution.

The basic transmission of education to economic growth is through participation of such educated individuals in the labor market. As important as it is for the citizens to be educated, it is much more important that these educated individuals participate actively in the productive sectors of the economy. Then it is important to understand how education translates to inclusive growth via higher education. Furthermore, the Sustainable Development Goals (SDGs) has its goal 8 as "promoting sustained, inclusive and sustainable economic growth, full and productive employment and decent work for all" by 2030. It should however be noted at this juncture that economic growth can only be sustainable in the long run if it is based on equity and inclusivity. Based on this background, this paper focuses mainly on enhancement of human capabilities which is one of the key drivers of IG. It assesses the performance of the indicators of human development in Nigeria and compares the outcomes with that of the emerging and developed nations. Finally due consideration is given to how HD translates to IG in a changing world. 


\section{Human Capital, Human Development and Inclusive Growth: The Link.}

Ranis, Stewart, and Ramirez (2000) found that out of the eight economic growth-lopsided nations in 1960-70, all of them moved through the vicious cycle of low economic growth/low human development. This conclusion only points to this argument; high economic growth not accompanied by increases in human capital development may prove to be ultimately unsustainable. Thus Ranis (2004) made an important conclusion "... human development seems to be a necessary prerequisite for long-term sustainable growth. The crucial lesson that emerges is that the old-fashioned view of "grow first and worry about human development later" is not supported by the evidence. Improving levels of education and health should have priority or at least move together with efforts to directly enhance growth".

Interestingly, Jorgenson and Fraumeni (1994) reveal that the US's investment in human capital, between 1948 and 1984, was almost 300\% the size of investment in physical capital. Consequently, in the same period, the value of productivity associated with human capital exceeded that of physical capital by over $900 \%$. Thus, the exclusion of human capital in national and public accounts greatly underestimates the true levels of investment and wealth in an economy. And without a proper estimation of a nation's asset, human capital inclusive, it will be difficult to know whether the economy is on a sustainable path of growth or not.Undoubtedly, increase in national income and per capita income cannot be explained in isolation of the quality of manpower and health status of the populace. At a conceptual level, increases in a person's stock of knowledge or human capital are assumed to raise his productivity in the market sector of the economy, where he produces income earnings, and in the nonmarket or household sector, where he produces commodities considerable in his utility function. A population of unskilled and unhealthy citizens surely earns lesser than a population of skilled citizens.

The differences among developed and developing nations can better be explained by differences in the endowments of human capital, rather than physical capital. This underscores the reason why the 'Asian Tigers' in the past three decades allocated between $25-35 \%$ of their annual budgets to the education sector. The Chinese Analyst, Yasheng (2009) argues that the true success factor for Chinese growth is the huge investments made in human capital development. Therefore, the idea that China succeeded because of its infrastructures is a misplaced argument. It is education that will pay-off in the long run, once a nation has the relevant growth in human capital, then infrastructure will be self-financed by the growth.

The African Development Bank (AfDB) emphasizes the fact that IG is all about growth coupled with equal opportunities and consists of economic, social and institutional dimensions. It is accompanied by lower income inequality. Ali and Son (2007) on the other hand defines IG as the growth process that increases the social opportunities function which depends on the average opportunities available to the population and how these opportunities are shared among the population. Ali concludes that the key elements in IG are employment and productivity, the development in human capabilities and social safety nets and the targeted intervention. IG has also been seen as GDP growth that leads to significant poverty reduction (Habitat, 2009). The Growth Report, 2010; Bhalla, 2007, Raunier and Kanbur, 2010, AfDB, 2013, Mckinley,2010 and Anand et al, 2013 all contributed significantly to the identification of the major drivers of IG in an economy. According to them, the outcome of IG is faster and it enhances sustainable economic growth. Thus for growth to be inclusive, it has to be proemployment. IG takes a long term perspective and focuses on productive employment rather than income distribution. It is only a productive labour force that can contribute and benefit 
from the development process of the economy. Furthermore, for economic growth to be inclusive, it has to be pro-poor. This implies that the average man (Nigerian) is expected to live above the poverty line which is only possible if economic activity in the economy keep increasing and not otherwise. IG needs to ensure income equality. These researchers emphasize that measures are needed to track the adverse distributional changes that affect not only the extremely and moderately poor, but also the disadvantaged non-poor. They submit that to curb increasingly income inequality, government need to design policies to expand job opportunities and access to social services and infrastructure for the regions and population. The enhancement of human capabilities is another identified vital prerequisite for IG. This is categorized as the supply side of IG model. It captures physical, mental and material wellbeing of the general populace, especially the working population. Empowerment for various categories of the composition of the country's population is not left out as they all enhance skillful performance at work. Here, the expectation is that due consideration is expected to be given to the working population as regards their acquisition of knowledge and skills which is necessary for productive employment. Access to health and education including other vital infrastructure such as safe drinking water and adequate sanitation decides the quality of human capital. Macroeconomic stability and human capital development are found to be the key determinants of inclusive growth in an emerging world. Gender Equity has also been identified as vital for economic growth to be inclusive.

In addition to sharing the benefits of economic growth, people must actively participate in the growth process. This explains why IG can be expressed as creating expansion of opportunities for participation which include both engagements in productive economic activities and having a part to play in the orientation of the growth process. Professor Schultz, best known for his pioneering works on education or formal schooling (1961) argues that education is an investment good and not consumption good as earlier believed. His estimates of social rates of return on education proved to be significantly high. According to him, there are five ways of developing human capital; the provision of health facilities which affect the life expectancy, strength, vigor and vitality of the people, the provision of on-the-job training which enhances the skill of labour force, improving education at the primary, secondary and higher levels, enhancing the study and extension programmes for the adults, and provision of adequate migration facilities to individuals adjusting to better job opportunities.

Becker (1965) provides an analytical framework for understanding investments in education, on-the-job training, vocational training and other forms of human capital. The subsequent emergence of the endogenous growth theory by the works of Romer (1986), Lucas (1988), Mankiw, Romer and Weil (1992) awaken the debate on the role of human capital as a determinant of economic growth. In some of these models, human capital induces growth by stimulating technological advancement and by enhancing labour productivity. Empirical evidence such as Romer (1986) and Lucas (1988) and the economic reality of the Asian Tigers corroborate the fact that human capital is a major driver of economic growth and macroeconomic performance of any nation (Durlauf, Johnson, and Temple 2004).

Human capital is the fundamental source of economic growth. It is a source of both increased productivity and technological advancement. Innovations, equipment and technology are engineered by human beings, made realistic by creative thinking, which is a product of the human mind. Of all forms of capital, the human capital remains the most relevant and Higher Education (HE) is the main source of that knowledge - its production, dissemination and its absorption by any society. Higher Education Institutions are a major source for producing the human capital required for knowledge production. It is however noteworthy today, that even if much knowledge is available at very low cost, its accessibility and use depends on human 
capacity to process and absorb it. In today's information societies, knowledge drives economic growth and development (IIEP, 2007). Economic growth currently depends on the capacity to produce knowledge based goods. However, the future of knowledge economy depends more on their capacity to produce knowledge through research and development, rather than on knowledge based goods. Hence, knowledge economies place greater value and accord higher priority to the production and distribution of knowledge. It is however noteworthy today, that even if much knowledge is available at very low cost, its accessibility and use depends on human capacity to process and absorb it. If a nation's capacity to produce knowledge is weak, its capacity to access and absorb it determines the pace at which that country develops (IIEP, 2007). Higher education plays a crucial role in enhancing a nation's human capacity to absorb and use knowledge. Then, if knowledge is a source of economic growth, disparities in its distribution become a source of inequalities among nations. Studies have shown that income inequalities are high where enrolments in HE are low. Individual benefits of HE include ensuring better employment, high salaries, and a greater ability to consume and save. HE emerges as an important variable contributing significantly toward improving individual earnings.

\section{Higher Education, Human Development and Economic Growth}

Mankiw, Romer and Weil (1992) in their studies have proved that HE has immeasurable impacts on economic growth and development. In the first way, it increases the human capital inherent in the labour force, which increases labour productivity and thus transitional growth towards a higher equilibrium level of output. HE can increase innovative capacity of the economy and the new knowledge on new technologies, products and processes; and consequently promotes growth as presented in theories of endogenous growth (Lucas 1988). Also, HE facilitates the diffusion and transmission of knowledge needed to understand and process new information. It helps to implement successfully new technologies devised by others which again promote economic growth. Proponents of human capital see it as the stock of economically productive human capabilities which can be formed by combining innate abilities with investments in human beings. In the past decade, Nigeria's average growth in GDP from 2005 - 2010 was 6.68\% (NBS,2012). This kept on declining and fluctuating to date. The 2014 rebasing of the GDP, which has seen the improved performance of service, industries like information communication technology, telecommunications, airlines, music, the film industry(Nollywood)and online retail outlets in the new valuation, made the country the $26^{\text {th }}$ largest economy in the world and the biggest in Africa. The recorded GDP was 510 billion dollars. However, recently in October, 2016, the International Monetary Fund (IMF) pronounced Nigeria again as having the largest economy in Africa despite its current multidimensional challenges. This is a position the country lost to South Africa in August, 2016. The IMF World Economic Outlook puts Nigeria's GDP at 415.08 billion dollars as against 493 billion dollars in 2015.Yet Africa's largest economy faces a myriad of challenges such as high prevalence of poverty, 13.3, 19.3 and 49.5 per cent levels of unemployment, underemployment and youth unemployment respectively, huge infrastructure deficits, income and social inequalities which has age, gender and location dimensions. Nigeria faces a tougher challenge in improving and implementing the relevant reforms directed at the education and health sector because it has historically so under-invested in it. It is the knowledge and skills that children and youth acquire that will drive their employability, productivity, health and wellbeing in the nearest future. They will ensure that their communities and nations thrive by contributing to the process of growth and development. Education is fundamental to growth and development. Literacy is one of the means of education and it is not the beginning or an end to it, rather it is an on-going process. Education helps one to understand a situation, take 
the challenge and explore the means to achieve goals. In as much as the role of higher education (HE) is immense, complex and vital. Universities are well positioned to link the local and global and this gives them considerable access to and influence over change process in many societies. HE enhances the potential to contribute to human and social development through the promotion and facilitation of citizen participation and involvement in the growth processes. Mankiw, Romer and Weil (1992) in their studies prove that HE has immeasurable impacts on economic growth and development. In the first way, it increases the human capital inherent in the labour force, which increases labour productivity and thus transitional growth towards a higher equilibrium level of output. HE can increase innovative capacity of the economy and the new knowledge on new technologies, products and processes; and consequently promotes growth as presented in theories of endogenous growth (Lucas 1988). Also, HE facilitates the diffusion and transmission of knowledge needed to understand and process new information. It helps to implement successfully new technologies devised by others which again promote economic growth. Educational attainment is however one of the key indices of human development and it is only when there is evidence of human development that there can be IG.

\section{Stylized facts on the assessment of the performance of drivers of knowledge in the Nigerian economy}

The competitiveness of economies is increasingly dependent on their capability to create, use and diffuse knowledge. The Global Competitive Ranking (GCR) assesses the ability of a country to provide high levels of prosperity to her citizens. The Global Competitiveness Index measures the set of institutions, policies and factors that set the sustainable current and medium- term levels of economic prosperity. The GCR for Nigeria was 124 out of 146 countries in 2015. This ranged between 94 and 127 from 2008 to 2015(Table 1 \& Fig. 1) (World Bank, Global Competitive Report, 2015). The World Bank ranking benchmark indicate that a rank of $1=$ the best GCR Furthermore, three key variables serve as proxies for each Knowledge Economy pillar. They are: Economic Incentive and Institutional Regime (EIR), Education, Innovation and Information Communications Technology (ICT). The EIR comprises of incentives that promote the efficient use of existing and new knowledge with flourishing entrepreneurship. An efficient innovation system made up of firms, research centers, universities, consultants and other organizations can tap into the growing stock of global knowledge, adapt it to local needs and create new technological solutions. An educated and appropriately trained population is capable of creating, sharing and using knowledge. The KEI for Nigeria in 2012 was 2.20 with a rank of 119 out of about146 (KEI, World Bank, 2012) (See Table 2). High KEI implies high ICT and Innovation ranking. With the World Bank benchmark for KEI, stating that 0 is the lowest while 10 is the highest. The KEI- Innovation Index for Nigeria is 2.56 in 2012(Table 2.3). This puts the innovation ranking for the country at 116. (KEI World Bank, 2012). The innovation indicators include; capacity for information mobilization, quality of scientific research institutions, spending on research and development (R\&D), University - Industry collaboration in R\&D, government procurement of advanced technology products and so on. The values of the indices and ranking out of 146 countries indicate that innovation system in Nigeria is weak and there is low level of R\&D activities in the country (World Economic Forum, 2014). The KEI - Innovation and GCR for Nigeria are classified as being on the low range. The 2014-2015 Global Competitiveness Report emphasizes the fact that Nigeria still lags behind in the area of innovation/ sophisticated production processes. Above all, the report emphasize that the firms capacity to absorb technology in Nigeria is still low compared with her counterparts in the emerging and developing nations. The country's products are also yet to compete favorably with the rest of the world markets. This confirms the fact that a nation's competitiveness and prosperity depends on the capacity of its industries to innovate and upgrade despite its resource endowments. 
Literacy rate (LR) is another indicator that measures the ability to read and write and acquisition of skills to access knowledge through technology. The literacy rate for Nigeria as reported by UNESCO 2015 stands as 59.6\% (See Table 2 \& Fig. 2.2). This is also categorized as low when compared with the sampled emerging and developed nation's ratings. Closely related to this is the KEI - Information and Communications Technology Index (ICT). A modern and accessible ICT infrastructure serves as a facilitator of the effective communication, dissemination and processing of information. The ICT index was 3.35 in 2012(Table 2 \&Fig.2.3).In comparison with the World Bank benchmark, the index is low as it is closer to 0 and farther from the highest value of 10. The Education Index (EI) is an indicator that rates the educated and appropriately trained population and the capability of that population to create, share and use knowledge. Nigeria's EI was 2.20 in 2012 which can still be categorized as low when compared with the UNESCO's benchmark of $0=$ lowest and 10 for the highest EI. Nigeria ranks 118 out of 140 countries (Table $2 \&$ Fig. 2.5). In the knowledge - based economy, the main source of value and competitive advantage in the new economy is human and intellectual capital. All these identified indicators of KEI are expected to guide the direction of investments and actions in an economy in order to ensure rapid transformation from KBE to a Creative Economy. Expenditures on Research and Development (R\&D) are current and capital spending on creative work undertaken systematically to increase knowledge of humanity, culture/society and the use of knowledge for new applications. Available statistics indicate that no data is inputted for Nigeria. This speaks volumes as regards the importance the nation attaches to R\&D(Table 4 \& Fig. 4). The Human Development Index (HDI) for Nigeria in 2012 and 2014 are 0.50 and 0.51 respectively (See Table $3 \&$ Fig.3). The World Bank benchmark however indicates that HDI of 1 implies the country is most developed. Nigeria ranks 152 out of 188 countries (World Bank, Human Development Report, 1980 - 2014). When compared with the HDI rankings of the sampled emerging and developed nations, Nigeria still lags behind in the average achievement in the three basic dimensions of human development which include a long, healthy life, and basic standard of living. This is further reflected in her life expectancy at birth data of 52.8 years in 2014(UNDP,2015).

As regards quality of life, the Gross National Income (GNI) per capita at 2011 Purchasing Power Parity \$, indicate explains further why Nigeria is categorized among countries with low human development(Table 5).

\section{Stylized facts on the assessment of the performance of drivers of knowledge in Emerging and Developed Nations: Lessons for Nigeria.}

The BRICS economies; Brazil, Russia, India, China and South Africa are distinguished by their large, fast - growing economies and significant influence on regional and global affairs. A KEI of 5.48 and 5.58 in 2000 and 2012 respectively, ranks Brazil at 60 out of 146 countries. The KEIInnovation and ICT range from 5.83 and 6.31 between 2000 and 2012 (See Table 2 and Fig.2.3). These indices are relatively high when compared to the World Bank Benchmark. The literacy rate is relatively high at $92.6 \%$ (Table 2 \& Fig. 2.2) surprisingly; the GCR is 75 out of about 146 economies. This ranking ranged between 48 and 75 from 2008 to 2015(Global Competitiveness Report, 2015). The HDI in Brazil is relatively high between 1990 and 2014.This is very close to 1 which is the World Bank upper limit bench mark (See Table 3 \& Fig. 3). Life expectancy at birth is also high at 74.5 years (UNDP2015). Expenditure on R\&D as percentage share of GDP between 2000 and 2012 was not up to $1.5 \%$ share of GDP, with high GNI per capita.(Table 4 \& fig. 4). The EI for Brazil in 2012 was 5.58 which is conveniently above average considering the World Bank benchmark (Table 2, \& Fig. 2.5) 
China's KEI- Innovation and ICT was 5.99 and 3.79 respectively in 2012 (Table 2 \&Fig. 2.3/ 2.4. The innovation index is relatively high while the ICT index is not up to average when considering the World Bank benchmark. Literacy rate is very high at $96.4 \%$ (See Table 2 \&Fig.2.2). The GCR is relatively high at 28, while for the HDI data is high at 0.91, with Life expectancy at birth as high as 84 years(UNDP,2014). Expenditure on R\&D as a percentage share of GDP between 2000 and 2012 is relatively fair compared to other nations. China also records high GNI per capita.

The South African economy is one of the BRICS economies. It is an economy that is efficiency driven. It possesses high quality institutions, intellectual property protection, efficient legal framework, accountability of private institutions and strong financial market development. It also has efficient markets for the distribution of goods and services. The KEI- Innovation, ICT and EI are all above average with the exception of KEI-ICT which was below average in 2012 . However her high Innovation Index indicates that the innovation system features good scientific research institutions and strong collaborations between universities and business sector. South Africa ranks 49 out of over 146 countries in the GCR. This is still relatively above average performance (See Table $1 \&$ Fig.1). Her HDI is 0.66 which ranks her in medium human development category (UNDP, 2015)( See Table 3\& Fig.3).

The developed nations record a high KEI- Innovation ICT, EI (Table 2 \& Fig. 2.4) This explains the progress made in the United States of America. New products/ services and more sophisticated production processes have emerged. The GCR for the United States is 3 which is not too distant from the World Bank benchmark in 2015. The implication of this recorded performance is that, there has been an enhanced increased global competition through reduced communication costs which have opened up new markets. Costs of international transport have reduced, while goods and services can be delivered via telephone contacts. Sizes of markets have increased. Products and services become quickly out of date which then means that businesses need to innovate more quickly and make use of its knowledge and creativity in order to survive.

Singapore can be categorized as an advanced emerging nation rated $2^{\text {nd }}$ most competitive country in the world and consistently being the highest ranked country in Asia in the last decade. A high share of Singapore's exports is classified as technology - intensive. So Singapore has worked effectively over the years to attain knowledge -based economy. A KEI of 8.26 in 2012 ranks the country 23 in the world (KEI, World Bank, 2012)(Table 2 \& Fig.2). Based on the country's capability to create, acquire, disseminate and apply knowledge to sustain its economic growth, capital and labour are becoming less important as drivers of economic growth. Singapore has benefitted so much from good governance, strong commitment towards development and good institutional frameworks. Singapore's 2012 ranking on EIR is $1^{\text {st }}$ in the world as the economy benefits from world - class infrastructure (excellent roads, ports, air transport facilities, sound macroeconomic environment and fiscal management. The KEI Innovation, ICT and Education Index are relatively high. They record 9.49, 8.78 and 5.09 respectively in 2012 (Tables $2.3,2.4 \& 2.5$ ). Her HDI and literacy rate are also very high. Life expectancy at birth is also high at 83 years(UNDP,2015). The GCR for Singapore ranks 2( See Table 1 \& Fig.1) out of over 140 countries in 2015 which is very close to the World bank bench mark of $1=$ the best. The Global Competitive Index was 5.6 in 2014. This is close to the extreme of the benchmark of 7(See Table 5). Literacy rate in 2015 was $94.3 \%$. All these indices indicate the nation's strong focus on education. The Singaporean workforce is highly educated and highly motivated, highly skilled and highly productive. Furthermore, the country produces diversified products such as electronics, transportation, equipment /machineries all of which are knowledge intensive (World Economic Forum. The Global Competitive Report, 2014-2015). 
Increased speed of scientific and technological advancement has also been experienced in the developed nations. Scientific researchers are on the increase and increased expenditures on research and development have led to the growth of scientific and technological knowledge. The high KEI indices is also transforming other sectors of the economy in terms of processes, nature of final product, branding and design all which account for increased demand for the produced goods and services. Innovation and creativity have been enhanced.

Sweden is another developed country with the most advanced knowledge economy. The country has strong institutions regarded as transparent and efficient, excellent infrastructure and healthy macroeconomic conditions with low levels of fiscal deficit. Sweden creates the right set of conditions for innovation and scores well with respect to royalty payments and receipts, science and engineering journal articles and patents. New goods are being produced with the use of sophisticated production process. Swedish firms are among the best performing in the world while its ICT adoption is among the highest in the world. For instance in 2012 the KEI - ICT Index was 9.49 which is very close to the extreme World Bank benchmark of 10. It has succeeded in building a strong knowledge foundation in both the public and private spheres of the society which translates into creativity. The nation records increase in infrastructural development and total factor productivity. It ranks 9 in its GCR for 2015, while it ranks 1 for the KEI of 9.43 in 2012, which is high following the World Bank Benchmark. Sweden is ranked among the countries in the very high human development category(UNDP, 2015)( See all relevant tables and figures).

\section{CONCLUSION AND RECOMMENDATIONS}

IG entails achieving sustainable growth that will create and expand economic opportunities and ensure broader access to these opportunities so that members of the society can participate in and benefit from economic growth. The general goal of HD on the other hand is to enhance the quality of human life which will enable people to live long and productive lives, enjoy good health, have access to knowledge and educational opportunities among others. The latest estimates from the International Monetary Fund, put Nigeria's GDP at 415.08 billion dollars thus regarding her as Africa's biggest economy. The expectation is that the resulting economic growth should be pro-employment, pro-poor, enhancing reduction in income and ensuring gender inequality. Utilizing secondary data and descriptive statistical analytical tools, this paper found out that the indices of human development and the knowledge economy recorded higher values (considering the World Bank bench mark) in the emerging and developed countries than what exists in the developing countries.

It is therefore recommended that the government through its policies should work harder and ensure that the GDP growth is inclusive thus ensuring sustainable human development rather than enhancing just higher income. The paper proceeds to remind the Nigerian government that economic development is all about human development and not just higher output and income. There is thus the urgent need for policy makers in Nigeria to understand explicitly the various dimensions of IG and formulate appropriate policy mix that will ensure the actualization of inclusive economic growth. Greater focus here should be on the components of human development index. Since knowledge acquisition via higher education has been identified as enhancing innovation and creativity, the innovation strategy will require policy leadership by the Ministry of Science and Technology. Such policies will be strengthened through co-operation across the three tiers of government. 
Human Capital via higher education is the key driver of growth in the knowledge economy characterized by IG and this will determine the extent of creativity and competitive position of the nation. Increased investment in human capital via education and health cannot be overemphasized. This will enhance improvements in the human development indices. Thus it becomes necessary for human capital development to be ensured via increased budgetary allocation to education with greater focus of government on quantity and quality of higher education. This will involve the government ensuring compliance with the United Nations benchmark on education expenditure. Institutional framework must ensure an adequate supply of appropriately qualified and skilled manpower in higher education. Review of primary, secondary and tertiary education curriculum, teaching methods, increased access to tertiary education, improved quality of teachers, teaching must be in tandem with the prevailing manpower needs. An appropriate student - teacher ratio, cannot be overemphasized at all levels of education. Vocational and Technical education will have to be given greater prominence to produce the required skills for a knowledge economy that can conveniently transform into a creative economy. No nation can develop beyond its investment in education.

There is also the need for greater networking and collaboration across all sectors of the economy (academia, science councils, industry and government). Thus an economic incentive and institutional regime that provides good economic policies and institutions must be in place. This will ensure efficient mobilization/ allocation of resources, stimulate creativity and incentives for the efficient creation, dissemination and use of existing knowledge. Furthermore, Human and Social Dynamics should be seriously revisited in Nigeria. This involves creating knowledge-intensive service sector such as education, communications and information. Establishing an educated, skilled, competitive and innovative workforce through optimum investment in human capital cannot be overemphasized. An improved funding mechanism, especially in the area of fund application for the necessary R\&D expenditures, and investment in appropriate infrastructures cannot be overemphasized. Higher education must be R\&D driven. This provides a basis for a well- functioning national innovative system. Presently no data is available on expenditure on R\& D by the government in Nigeria. This speaks volumes as regards the nation's commitment to such. Furthermore, a modern and adequate information infrastructure will facilitate the effective communication, dissemination and processing of information and knowledge. There is the need to reconcile traditional methods of production with new methods generated through basic research efforts and educating new generations of scientists and engineers. Above all, there is the need to translate technological change into productivity gains via human development and increased output growth.

\section{References}

Adelakun, O.J. (2011). Human Capital Development and Economic Growth in Nigeria. European Journal of Business and Management; 3(9) 2011. Available online at www.iiste.org.

Ali, I and Son, H (2007). Measuring Inclusive Growth. Asia Development Review. 24(1) Pp 11-31.

Becker G.S. (1965). Human Capital: A Theoretical and Empirical Analysis.Princeton N.J.Princeton University Press

Durlauf S.N, Johnson P.A and Temple J.R.W (2004). Growth Econometrics. .Department of Economics. University of Wisconsin, 1180 Observatory Drive, Madison, WI 53706-1393.United States.

International Institute for Educational Planning. Newsletter (IIEP) Vol. xxv, No.1, January -March, 2007.

Jorgenson, D.W., and Fraumeni B.M. (1994). The Accumulation of Human and Nonhuman Capital, 1948-1984, chapter 5 of Investment and Economic Growth, presented at The Simon Kuznets Lectures, Yale University.

Kwon D. (2009). Human Capital and its Measurement. The $3^{\text {rd }}$ OECD World Forum on and Policy Charting Progress, Building Visions, Improving Life Busan, Korea 27-30 Oct. 2009.

Statistics, Knowledge

Lucas, R.E. (1988), On the Mechanics of Economic Development. Journal of Monetary Economics 22. 
Malhotra Y. (2003). Measuring Knowledge Assets of a Nation: Knowledge Systems for Development. Research Paper Delivered at the United Nations Advisory Meeting of the Department of Economic and Social Affairs Division for Public Administration and Development Management. United Nations Headquarters, New York, US.

Mankiw, G., D. Romer and D. Weil (1992). A Contribution to the Empirics of Economic Growth:Quarterly Journal of Economics 107, pp 407-37. The MIT Press.

Mckinley, T (2010) Inclusive Growth Criteria and Indicators: An Inclusive Growth Index forDiagnosis of Country Progress. No. 14, June.

Oladeji, S.I (2014). Educated and Qualified, But Jobless: A Challenge for Sustainable Development in Nigeria.Inaugural Lecture Series.262. ObafemiAwolowo University,Ile - Ife. Nigeria

Pritchett, L. (1999-a).Where Has All the Education Gone? Policy Research Working Paper, WorldBank. Washington D.C.

Ranis G. (2004). Human Development and Economic Growth. Center Discussion Paper No. 887.Economic Growth Center .Yale University. Available online: http://www.econ.yale.edu/ egcenter/.

Ranis, Gustav and Frances Stewart (2000). Strategies for Success in Human Development. Journal of Human Development, Vol. 1, No. 1.

Raunjiyar,G and Kabur, R (2010) Inclusive Development : Two Papers on Conceptualization, Application and the ADB Perspective. Unpublished.

Riley G. (2001). Human Capital and Economic Growth. Available at: www.tutor2u.net/blog/index.php/economics/comments/unit-4-macro-human-capital-and-economic-growth.

Thomas A. (2008). Strategic Human Capital Plan 2009 - 2014. National Archives and Records Administration (NARA).Archives of the United States of America. Washington D.C.

United Nations Economics Commission for Africa UNECA, (1990). Hand book of Manpower planning in Africa. UNECA, Addis Ababa.

Vallela, I, (2014) ADB Sustainable Development. Working Paper Series. No. 14.

Yasheng H. (2009). Human Capital Development: The reason behind China's Growth. The Economic Times. Available online: http://economictimes.indiatimes.com.

World Bank, (2013\& 2015) Human Development Report, UNDP 2013, hdr.undp.org.2013 \& 2015-Report

World Bank, (2012) Knowledge Economy Index.

World Economic Forum, (2014, 2015) Global Competitiveness Report. 


\section{APPENDICES}

Table 1: GLOBAL COMPETITIVE RANKING (GCR)

\begin{tabular}{|r|l|r|r|r|l|r|}
\hline & \multicolumn{2}{|c|}{ GCR } & & & & \multicolumn{1}{l|}{ GCR } \\
\hline S/N & Country & 2015 & & S/N & Country & 2015 \\
\hline 1 & Tunisia & 92 & & 15 & Uganda & 115 \\
\hline 2 & Botswan & 71 & & 16 & Nigeria & 124 \\
\hline 3 & Brazil & 75 & & 17 & Cameroon & 114 \\
\hline 4 & Malaysia & 18 & & 18 & Malawi & 135 \\
\hline 5 & South Africa & 49 & & 19 & Tanzania & 120 \\
\hline 6 & Mauritus & 46 & & 20 & Singapor & 2 \\
\hline 7 & China & 28 & & 21 & Germany & 4 \\
\hline 8 & India & 55 & & 22 & UAE & 17 \\
\hline 9 & Ghana & 119 & & 23 & Italy & 43 \\
\hline 10 & Kenya & 99 & & 24 & Canada & 13 \\
\hline 11 & Madagas car & 130 & & 25 & Ireland & 24 \\
\hline 12 & Maurtania & 138 & & 26 & USA & 3 \\
\hline 13 & Jordan & 64 & & 27 & Switzerland & 1 \\
\hline 14 & Senegal & 110 & & 28 & Sweden & 9 \\
\hline
\end{tabular}

Source: Global Competitiveness Report, World Economic Fonum,2015

Key: Rank $1=$ best

Figure 1

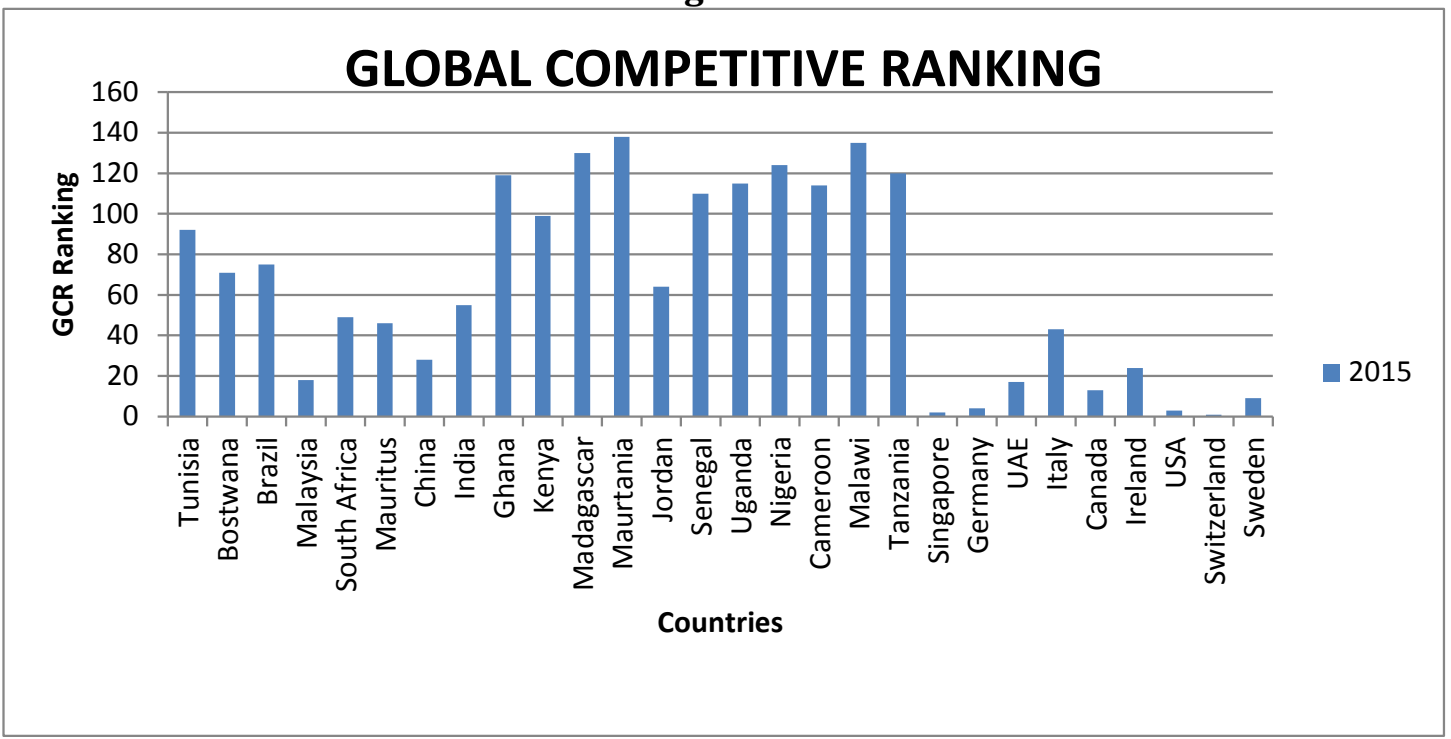




\begin{tabular}{|c|c|c|c|c|c|c|c|c|c|c|}
\hline \multicolumn{2}{|l|}{ Table 2} & \multicolumn{7}{|c|}{ KNNOWVLWDGE ECONOMMY INDEX } & \multirow{2}{*}{\multicolumn{2}{|c|}{\begin{tabular}{|l|} 
\\
Education Inde $x$
\end{tabular}}} \\
\hline & KEI & KEI & $\mid$ Literacy & 1 KEI-ICT & Index & |KEI-Inno & vation Ind & dex & & \\
\hline Country & 2000 & 2012 & 2012 & 2000 & 2012 & 200 & 2012 & & 2012 & \\
\hline Tunisia & 4.15 & 4.56 & 81.8 & 4.54 & 4.89 & 4.24 & 4.97 & & 4.56 & \\
\hline Botswana & 4.99 & 4.31 & 88.5 & 5.22 & 3.23 & 4.35 & 4.26 & & 4.31 & \\
\hline Brazil & 5.48 & 5.58 & 92.6 & 5.93 & 6.24 & 6.31 & 6.23 & & 5.58 & \\
\hline Malaysia & 6.37 & 6.1 & 94.6 & 7.34 & 6.61 & 6.91 & 6.62 & & 6.1 & \\
\hline South Afr & 5.77 & 5.21 & 94.3 & 6.28 & 3.58 & 6.89 & 6.78 & & 5.21 & \\
\hline Mauritus & 5.36 & 5.52 & 90.6 & 6.93 & 5.11 & 4.41 & 4.23 & & 5.52 & \\
\hline China & 3.83 & 4.37 & 96.4 & 4.8 & 3.79 & 4.35 & 5.99 & & 4.37 & \\
\hline India & 3.14 & 3.06 & 72.1 & 2.85 & 1.9 & 3.83 & 4.5 & & & \\
\hline Ghana & 3 & 2.72 & 76.6 & 2.81 & 1.93 & 2.21 & 2.24 & & 2.72 & \\
\hline Kenya & 2.93 & 2.88 & 78 & 2.1 & 2.91 & 4.19 & 3.72 & & 2.88 & \\
\hline Madagasc & 2.01 & 1.77 & 64.7 & 1.84 & 1.1 & 2.68 & 2.37 & & 1.77 & \\
\hline Maurtania & 2.09 & 1.65 & 52.1 & 2.81 & 2.18 & 1.66 & 1.68 & & 1.65 & \\
\hline Jordan & 5.58 & 4.95 & & 5.22 & 4.54 & 6.2 & 4.05 & & 4.95 & \\
\hline Senegal & 3.15 & 2.7 & 55.7 & 3.35 & 2.68 & 3.04 & 2.83 & & 2.7 & \\
\hline Uganda & 2.16 & 2.37 & & 2.1 & 1.88 & 2.68 & 2.54 & & 2.37 & \\
\hline Nigeria & 2.09 & 2.2 & 59.6 & 2.35 & 3.35 & 2.84 & 2.56 & & 2.2 & \\
\hline Cameroon & 2.17 & 1.69 & 75 & 2.3 & 1.56 & 2.84 & 2.61 & & 1.69 & \\
\hline Malawi & 2.21 & 1.92 & 65.8 & 1.84 & 1.15 & & 2.65 & & 1.92 & \\
\hline Tanzania & 2.02 & 1.79 & 80.3 & 2.1 & 1.26 & 2.23 & 1.98 & & 1.79 & \\
\hline Singapore & 8.57 & 8.26 & & & 8.78 & & 9.49 & & 5.09 & \\
\hline Germany & 8.84 & 8.9 & & & 9.17 & & 9.11 & & 8.2 & \\
\hline UAE & 6.05 & 6.94 & & & 8.88 & & 6.6 & & 5.8 & \\
\hline Italy & 7.98 & 7.98 & & & 8.21 & & 8.01 & & 7.58 & \\
\hline Canada & 9.07 & 8.92 & & & 8.23 & & 9.32 & & 8.61 & \\
\hline Ireland & & & & & 8.21 & & 9.11 & & 8.87 & \\
\hline USA & 9.28 & 8.77 & & & 8.51 & & 9.46 & & 8.7 & \\
\hline Switzerlan & 9.28 & 8.87 & & & 9.2 & & 9.86 & & 6.9 & \\
\hline \multirow[t]{4}{*}{ Sweden } & 9.65 & 9.43 & & & 9.49 & & 9.74 & & 8.92 & \\
\hline & & & & & & & & & & \\
\hline & & \multicolumn{7}{|c|}{ KNNOWVWVDGE ECONOMY INDEX } & & \\
\hline & KEI & KEI & Lite racy 1 & Rate & KEI-ICT & Index & KEI-Inno & Vvation Ind & \begin{tabular}{|l|} 
Education \\
\end{tabular} & Index \\
\hline \multirow[t]{15}{*}{ Country } & & & -140.15 & -197.99 & $|-130.79|$ & -228.58 & $-130.52 \mid$ & & -133.35 & \\
\hline & Source: & & & & \\
\hline & & & & & & & & & & \\
\hline & & \multicolumn{3}{|c|}{$\begin{array}{l}\text { UNESCO Institute for Statis } \\
\text { (Literacy Rate Data, } 2015 \text { ) }\end{array}$} & & & & & & \\
\hline & & & & & & & & & & \\
\hline & key & & & & Ranking & & & & & \\
\hline & \multirow{2}{*}{\multicolumn{3}{|c|}{$\begin{array}{l}\text { KEI Innovation Index } \\
O=\text { Lowe }, 10=\text { Highest }\end{array}$}} & & \multicolumn{4}{|c|}{ Nigeria Ranks 116 out of 145} & & \\
\hline & & & & & & & & & & \\
\hline & & & & & & & & & & \\
\hline & & & & & & & & & & \\
\hline & KEI-ICT & Index & & & \multicolumn{4}{|c|}{ Nigeria rank 101 out of 145} & & \\
\hline & $\mathbf{O}=$ Lowe & \multicolumn{2}{|c|}{$10=$ Highest } & & & & & & & \\
\hline & & & & & & & & & & \\
\hline & $\mathbf{K E I}=\mathbf{K}_{\mathbf{I}}$ & nowledge & Economy & y Index & & & & & & \\
\hline & $\mathbf{O}=$ Lowe &, $\mathbf{1 O}=\mathrm{His}$ & ghest & & & & & & & \\
\hline
\end{tabular}

Figure 2.1

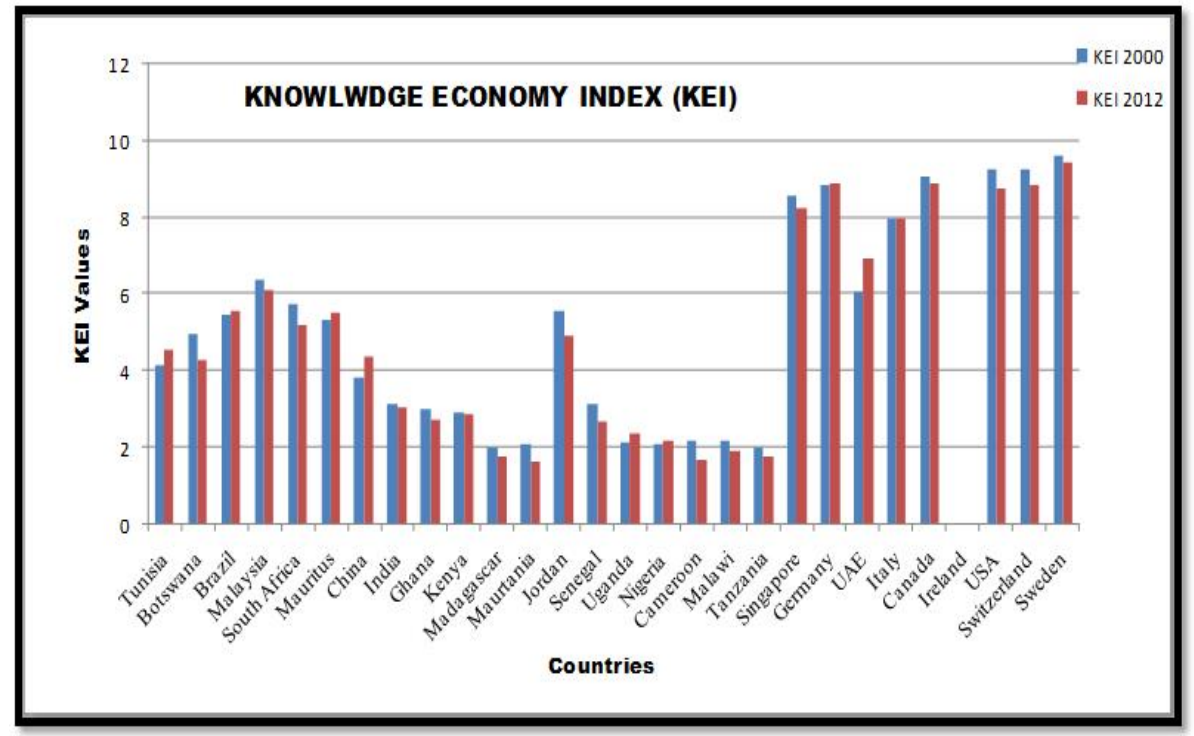


Figure 2.2

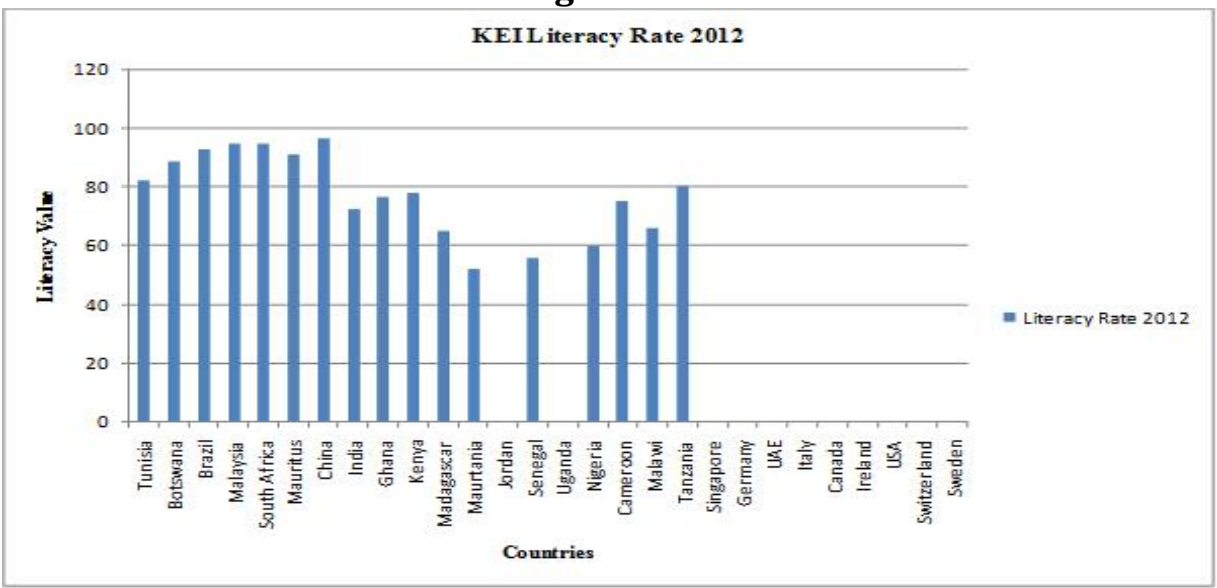

Figure 2.3

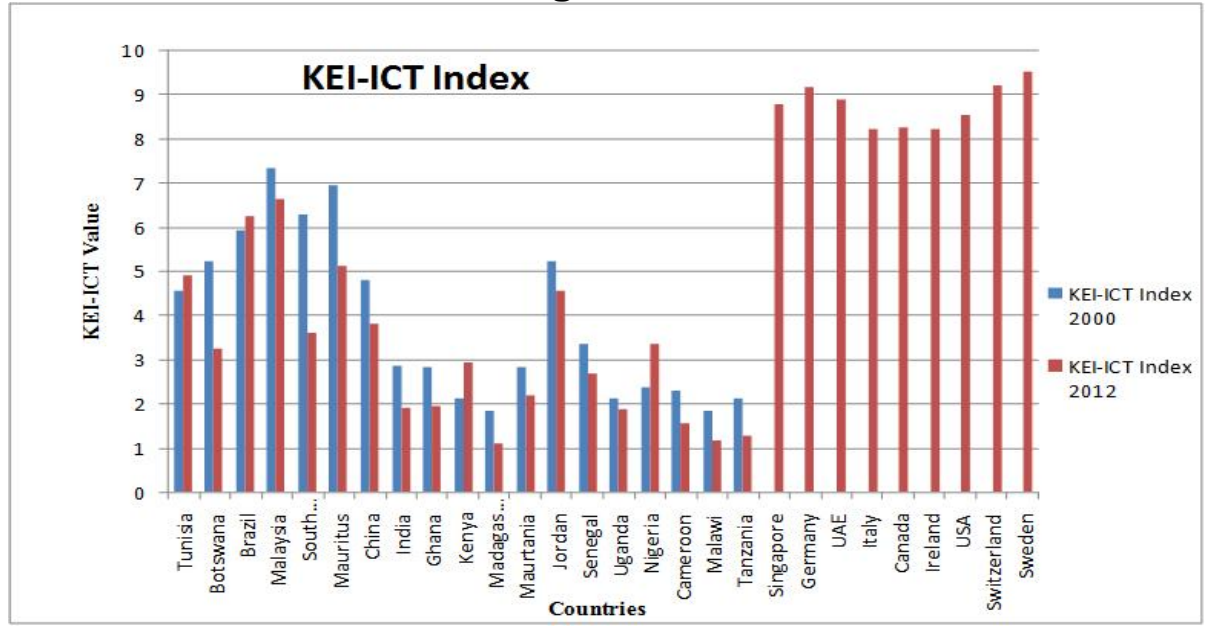

Figure 2.4

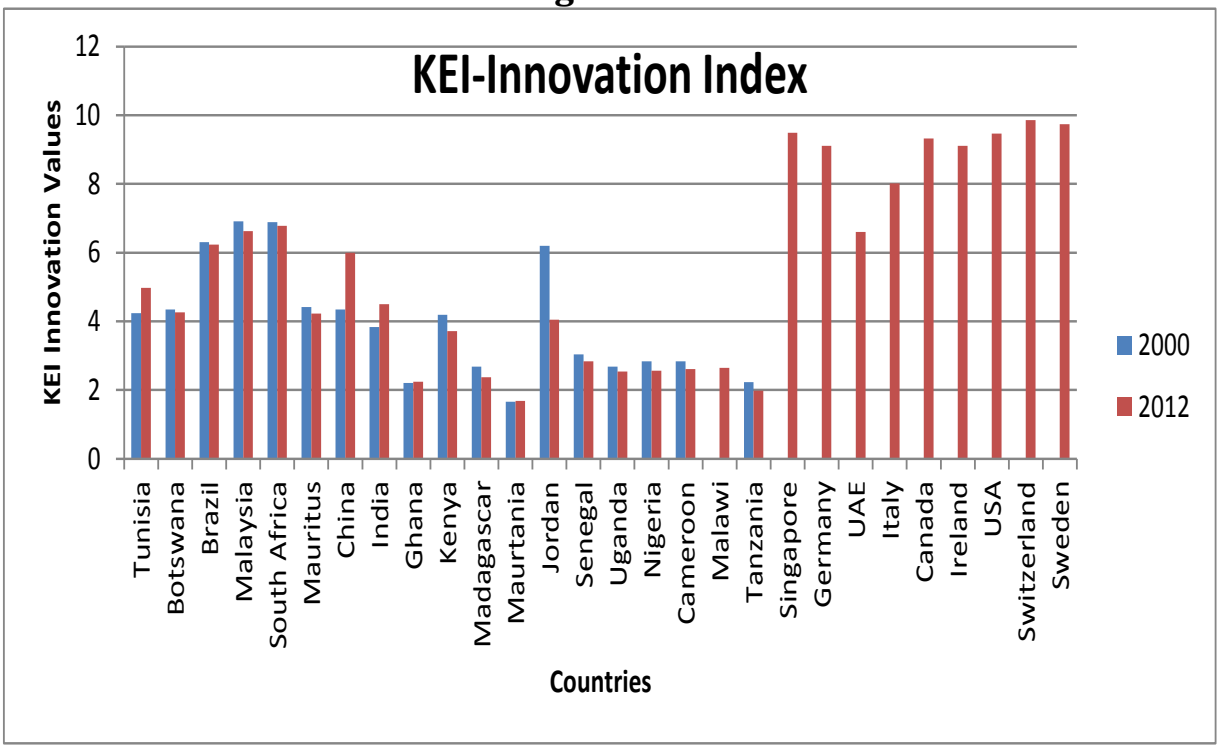


Figure 2.5

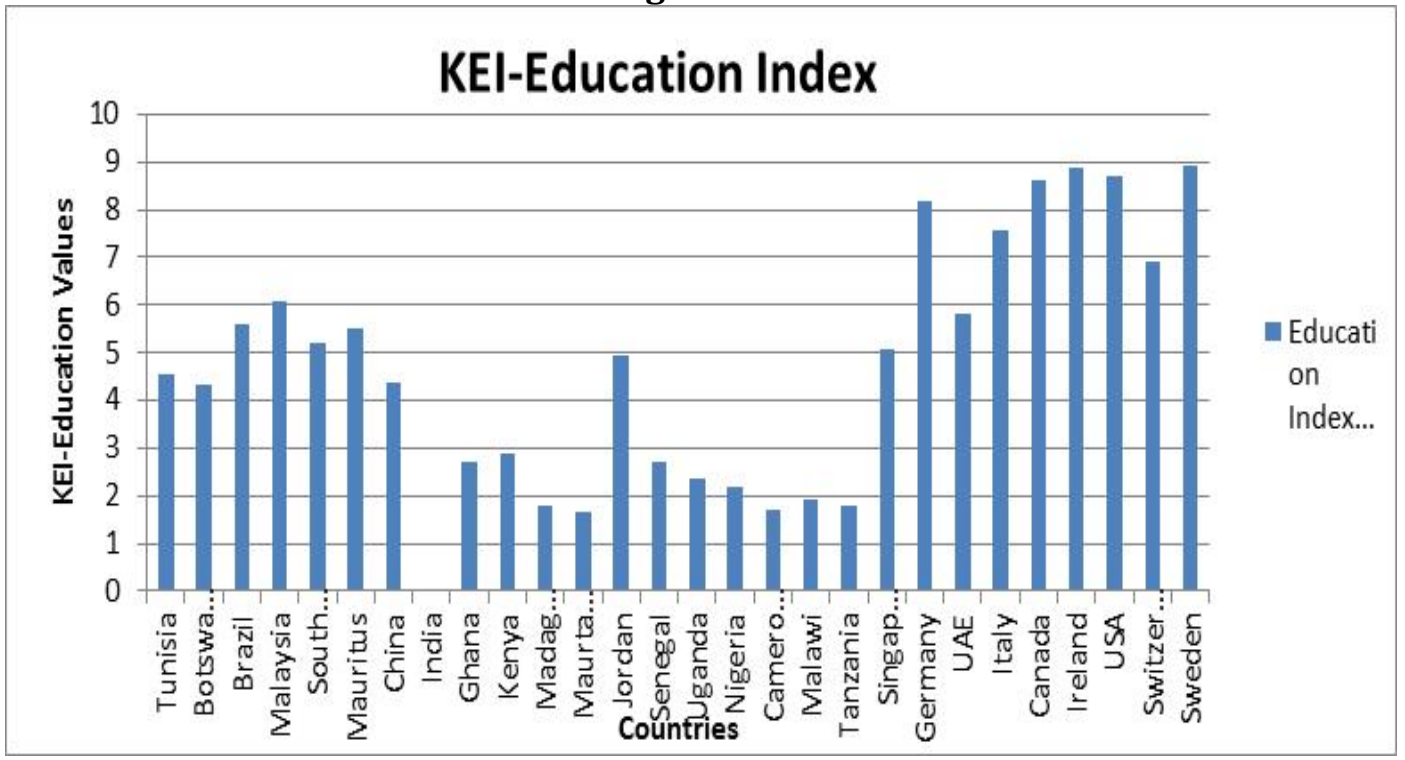

\begin{tabular}{|c|c|c|c|c|c|c|c|c|c|}
\hline Country & 1990 & 2000 & 2005 & 2008 & 2009 & 2010 & 2011 & 2012 & 2014 \\
\hline \multicolumn{10}{|l|}{ China } \\
\hline India & 0.43 & 0.48 & 0.53 & 0.55 & 0.55 & 0.57 & 0.58 & 0.58 & 0.61 \\
\hline Tunisia & & 0.69 & 0.71 & 0.71 & 0.72 & 0.72 & 0.72 & 0.72 & 0.72 \\
\hline Botswana & 0.58 & 0.56 & 0.61 & 0.66 & 0.66 & 0.67 & 0.68 & 0.68 & 0.7 \\
\hline Brazil & 0.61 & 0.68 & 0.71 & 0.73 & 0.73 & 0.74 & 0.74 & 0.74 & 0.76 \\
\hline Malaysia & 0.64 & 0.72 & 0.75 & 0.76 & 0.76 & 0.77 & 0.77 & 0.77 & 0.78 \\
\hline South Afr & 0.62 & 0.63 & 0.61 & 0.62 & 0.63 & 0.64 & 0.65 & 0.65 & 0.67 \\
\hline Mauritus & 0.62 & 0.69 & 0.72 & 0.74 & 0.75 & 0.75 & 0.76 & 0.77 & 0.78 \\
\hline Tanzania & 0.35 & 0.38 & 0.42 & 0.45 & 0.46 & 0.46 & 0.48 & 0.48 & 0.52 \\
\hline Jordan & 0.62 & 0.71 & 0.73 & 0.75 & 0.75 & 0.74 & 0.74 & 0.74 & 0.75 \\
\hline Ghana & 0.5 & 0.49 & 0.51 & 0.54 & 0.55 & 0.56 & 0.57 & 0.57 & 0.58 \\
\hline Kenya & 0.47 & 0.46 & 0.48 & 0.51 & 0.52 & 0.52 & 0.53 & 0.53 & 0.55 \\
\hline Uganda & 0.31 & 0.39 & 0.43 & 0.46 & 0.47 & 0.47 & 0.48 & 0.48 & 0.48 \\
\hline \multicolumn{2}{|c|}{ Madagascar } & 0.45 & 0.47 & 0.49 & 0.5 & 0.49 & 0.49 & 0.5 & 0.51 \\
\hline Maurtania & 0.37 & 0.43 & 0.46 & 0.47 & 0.47 & 0.47 & 0.48 & 0.48 & 0.51 \\
\hline Senegal & 0.38 & 0.41 & 0.45 & 0.47 & 0.48 & 0.48 & 0.48 & 0.48 & 0.47 \\
\hline Nigeria & & & 0.47 & 0.48 & 0.49 & 0.49 & 0.5 & 0.5 & 0.51 \\
\hline Malawi & 0.28 & 0.34 & 0.37 & 0.4 & 0.41 & 0.41 & 0.41 & 0.41 & 0.45 \\
\hline Cameroor & 0.44 & 0.43 & 0.46 & 0.48 & 0.49 & 0.49 & 0.5 & 0.5 & 0.51 \\
\hline Singapore & 0.74 & 0.8 & 0.84 & 0.87 & 0.87 & 0.89 & 0.9 & 0.9 & 0.91 \\
\hline Germany & 0.78 & 0.85 & 0.89 & 0.9 & 0.9 & 0.91 & 0.91 & 0.91 & 0.92 \\
\hline UAE & 0.73 & 0.8 & 0.82 & 0.83 & 0.83 & 0.82 & 0.82 & 0.82 & 0.84 \\
\hline Italy & 0.76 & 0.82 & 0.86 & 0.87 & 0.87 & 0.87 & 0.87 & 0.87 & 0.87 \\
\hline Canada & 0.85 & 0.87 & 0.89 & 0.9 & 0.89 & 0.9 & 0.9 & 0.9 & 0.91 \\
\hline Ireland & 0.77 & 0.86 & 0.89 & 0.9 & 0.9 & 0.9 & 0.9 & 0.9 & 0.92 \\
\hline USA & 0.86 & 0.88 & 0.9 & 0.91 & 0.91 & 0.91 & 0.91 & 0.91 & 0.91 \\
\hline Switzerlar & 0.83 & 0.89 & 0.9 & 0.9 & 0.91 & 0.91 & 0.91 & 0.92 & 0.93 \\
\hline Sweden & 0.81 & 0.89 & 0.89 & 0.89 & 0.89 & 0.9 & 0.9 & 0.9 & 0.91 \\
\hline
\end{tabular}

SOURCE: World Bank, Human Development Report, 1980-2014 
Figure 3

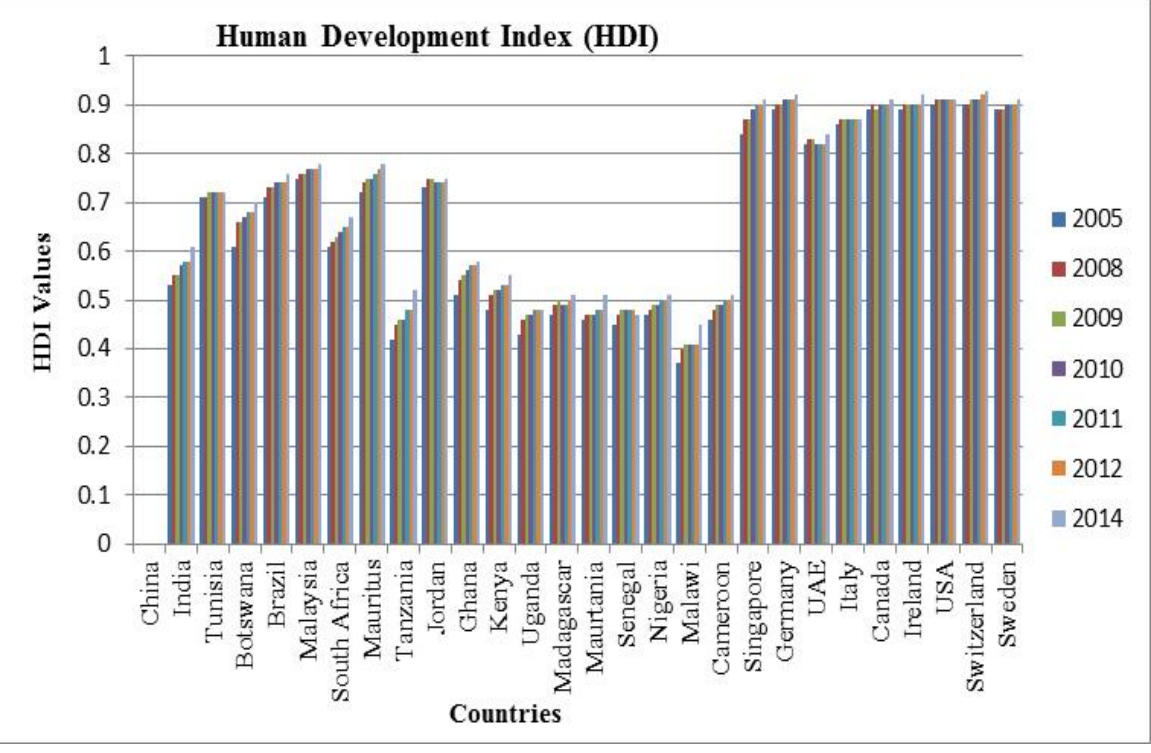

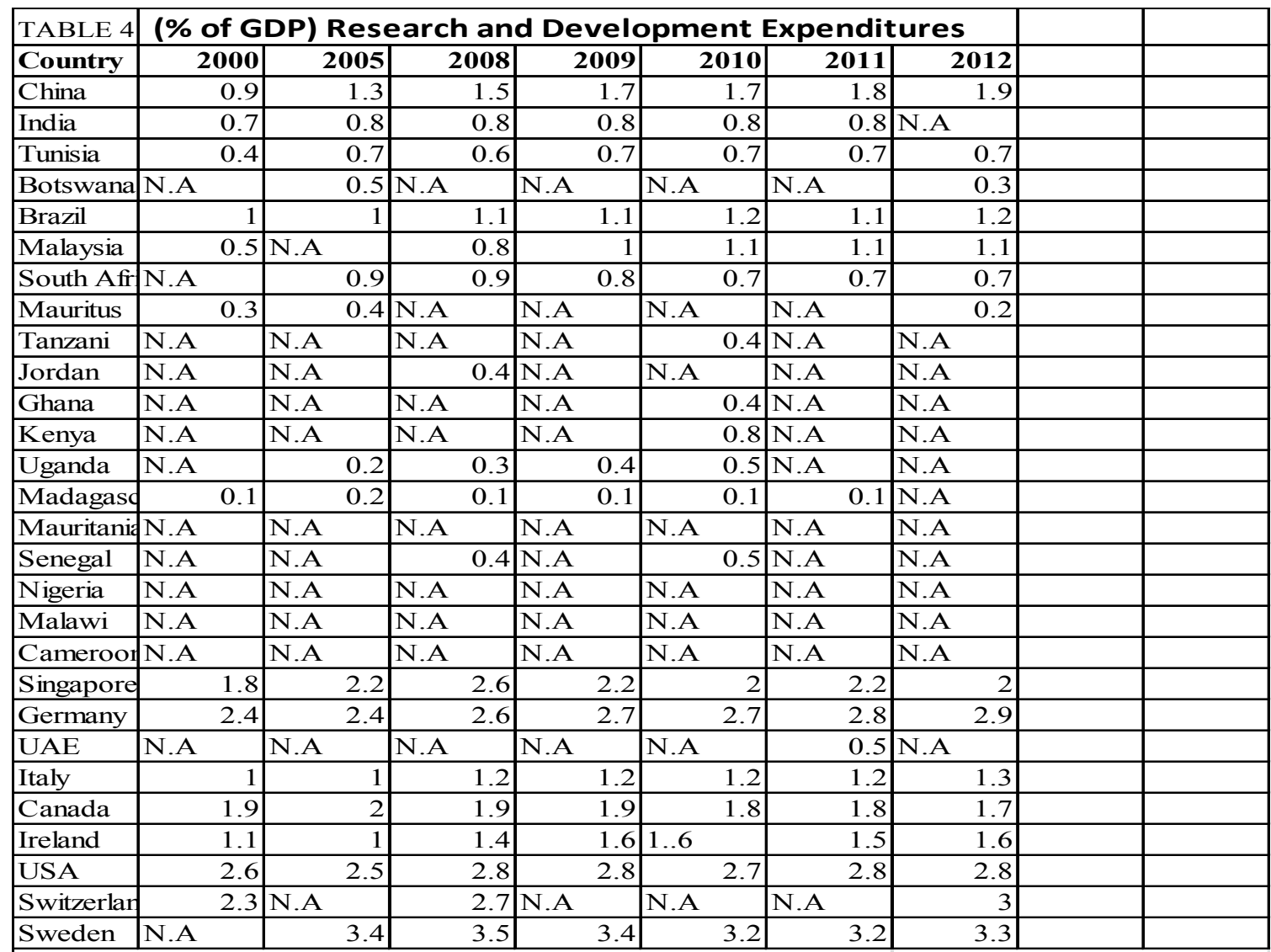

Source : World Development Indicators ( WDI, December, 2015) Key: N.A- Not Available 
Figure 4

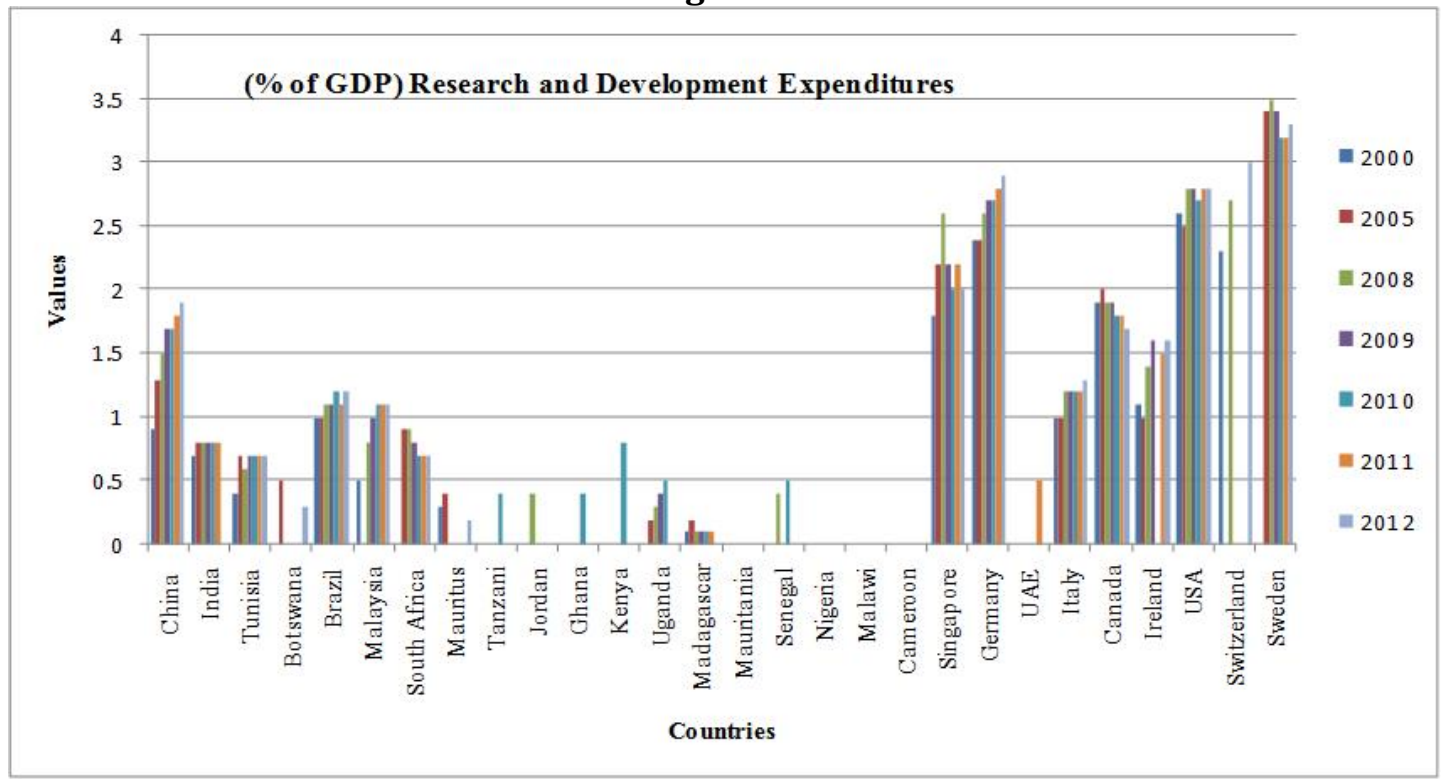

\begin{tabular}{|l|r|r|r|r|r|r|r|}
\hline & \multicolumn{6}{|l|}{ Table 5: KEY ECONOMIC INDICTATORS } \\
\hline & \multicolumn{2}{|c|}{ Population (Millions) } & GDP (USA \$ Billion) & KEI Score 1-10 & GCI Score 1-7 \\
\hline Coutry & $\mathbf{2 0 1 3}$ & $\mathbf{2 0 1 3}$ & $\mathbf{2 0 1 2}$ & $\mathbf{2 0 1 4}$ & \\
\hline Sweden & 9.6 & & 557.9 & 9.43 & & 5.4 & \\
\hline Singapore & 5.4 & & 295.7 & 8.26 & & 5.6 & \\
\hline South Korea & 50.2 & & 1221.8 & 7.97 & 5 & \\
\hline South Africa & 53 & & 350.8 & 5.21 & & 4.4 & \\
\hline Nigeria & 169.3 & & 286.5 & 2.2 & & 3.4 & \\
\hline
\end{tabular}

Source: World Economic Forum, 2014

World Bank, 2012

Key $=\mathrm{GCl}$ Global Competitive Index 